\title{
Infraspecific Variability in the Essential Oil Composition of Lychnophora ericoides
}

\author{
Cynthia C. G. V. Lyra, ${ }^{a}$ Roberto F. Vieira, ${ }^{b}$ Carolina B. A. de Oliveira, ${ }^{c}$ Suzana C. Santos, ${ }^{c}$ \\ José C. Seraphin ${ }^{d}$ and Pedro H. Ferri ${ }^{*}, c$
}

${ }^{a}$ Universidade Católica de Brasília, SGAN 916 Módulo B, 70790-160 Brasília-DF, Brazil

${ }^{b}$ Embrapa Recursos Genéticos e Biotecnologia, CP 02372, 70770-900 Brasília-DF, Brazil

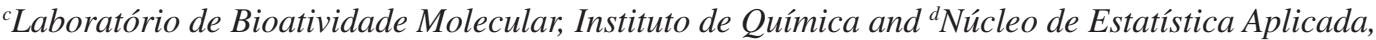
Instituto de Matemática e Estatística, Universidade Federal de Goiás, CP 131, 74001-970 Goiânia-GO, Brazil

A variação na composição química do óleo essencial das folhas em três populações silvestres de Lychnophora ericoides, com ou sem odor, indicou a presença de dois grupos de óleos em relação ao odor das amostras. O primeiro incluiu amostras de odor aromático contendo altas percentagens de $\alpha$-bisabolol (34 $\pm 23 \%$ ) e $o$-cimeno $(8,4 \pm 6,9 \%)$. No grupo II, as amostras não apresentaram qualquer odor e os constituintes majoritários foram o óxido de cariofileno (11 \pm $9 \%)$ e o $\delta$-elemeno $(5,7 \pm 6,9 \%)$. Em todas as populações estudadas co-existem os dois tipos de óleos, embora a maioria das amostras aromáticas provenientes do Parque Estadual da Serra de Caldas Novas se diferenciem quimicamente daquelas do Parque Nacional de Brasília e de Santo Antônio do Descoberto. As variações químicas sugerem claramente, além da influência geográfica, diferenças genéticas entre indivíduos nas populações. $O$ alto conteúdo de $\alpha$-bisabolol suporta $o$ uso medicinal folclórico de arnica como antiinflamatório.

Variations in the composition of the leaf essential oils of wild Lychnophora ericoides, with and without scent, which were grown in three sampling sites, were examined by GC-MS. Results were submitted to principal component and cluster analysis which allowed for two groups of essential oils to be distinguished with regard to scent: cluster I with specimens exhibiting an aromatic scent and containing a high percentage of $\alpha$-bisabolol $(34 \pm 23 \%)$ and $o$-cymene $(8.4 \pm 6.9 \%)$; cluster II with specimens without any scent and characterised by a high percentage of caryophyllene oxide $(11 \pm 9 \%)$ and $\delta$-elemene $(5.7 \pm 6.9 \%)$. The two types of oil coexist in all the populations under study, although patterns of aromatic samples deriving from Caldas Novas' State Park reveal chemical differences in relation to the samples from Brasília's National Park and Santo Antônio do Descoberto. Such chemical variations clearly suggest, apart from a geographical influence, genetic differences between individuals in the populations. The high content of $\alpha$-bisabolol supports the folk medicinal use of arnica as anti-inflammatory.

Keywords: Lychnophora ericoides, Asteraceae, essential oils, chemical variability

\section{Introduction}

The genus Lychnophora Mart. (Asteraceae) consists of approximately 34 species, all of which grow in restricted regions of central Brazilian Cerrado at altitudes ranging from 950 to $1800 \mathrm{~m}$ above sea level in sandy sites, usually inside woodland and scrubs. ${ }^{1-3} L$. ericoides Mart. is the most popular species, whose leaves are frequently aromatic and commercialised in local markets as analgesic and anti-inflammatory agents. ${ }^{4,5}$ Its characteristic constituents

*e-mail: pedro@quimica.ufg.br are sesquiterpene lactones showing antiproliferative activity, ${ }^{6-8}$ as well as flavonoids with anti-inflammatory effects, ${ }^{9}$ triterpenes, ${ }^{7,10}$ lignans, and caffeoylquinic acids with analgesic activity. ${ }^{4,11}$

In the first phytochemical study of the essential oil of L. ericoides we identify a high degree of variability in the quantity and composition of leaf essential oils from wild populations with and without scent, each one growing on different sites. ${ }^{12}$ One ecotype was characterized by specimens lacking any kind of scent and featuring a very large content of $(E)$-nerolidol. The other ecotype was distinctive for its aromatic scents, with $\alpha$-bisabolol as its 
main constituent. The high correlation obtained for the two populations with edapho-climactic factors and the high variance supported by environmental data have been used to understand the observed chemical polymorphism. ${ }^{12}$

We now report on the results obtained for the essential oil composition and variability from populations of $L$. ericoides with and without scent, all of them native of the same natural environment. For this purpose, three sampling sites were chosen and each represented the two different types (Figure 1). In order to study the chemical variability the chemical constituents of the essential oils from leaves were submitted to multivariate analysis such as amount or presence/absence code in order to detect the pattern distribution of samples and to identify which constituents are able to differentiate between these groups of individuals.

The variation pattern in the essential oil indicate that the observed chemical variations could be due to the existence of genetically determined chemotypes for $L$. ericoides which have not yet been described for Lychnophora species.

\section{Results and Discussion}

The essential oils of aromatic L. ericoides, collected from three different sampling sites, gave an average yield of $0.52 \pm 0.22 \mathrm{wt} \%$. The mean yield of oils from Caldas Novas' State Park (CN) (0.38 $\pm 0.18 \%)$ was lower than that of plants growing in Brasília's National Park (BN) $(0.63 \pm 0.16 \%)$ and Santo Antônio do Descoberto
(SA) $(0.62 \pm 0.20 \%)$. Scentless samples yielded oils in such low amounts that they prevented any quantitative evaluation.

In total, 143 constituents were detected, of which 105 could be identified, but with 19 major components accounting for mean contents of $73 \pm 17 \%$ of volatile constituents (data not shown). The remaining compounds were each in small amounts (mean content less than 1.0\%). The major constituents of essential oils are presented in Table 1, arranged in order of elution. The main group of constituents in the majority of samples was composed of oxygenated sesquiterpenes $(0.74-92 \%)$. L. ericoides without scent was characterised by the absence or trace amounts of monoterpenes, regardless of the sampling sites, while scented samples from $\mathrm{CN}$ revealed monoterpene hydrocarbons with a high mean content $(43 \pm 14 \%)$ $(p<0.05)$. In this site, $o$-cymene $(17 \pm 6 \%)$ and $\alpha$-thujene $(13 \pm 6 \%)$ were the major constituents, while $\alpha$-bisabolol occurred in the lowest mean content $(0.7-39 \%)$. In other sites, $\alpha$-bisabolol, which features an important antiinflammatory activity, ${ }^{13}$ revealed a higher mean content $(46 \pm 17 \%)(p<0.05)$. All essential oil components, with the exception of n-nonanal, ar-curcumene, and other constituents (Table 1), showed interactions between populations and sampling sites.

The results obtained from principal component (PCA) and cluster analysis using Ward's technique with oil constituent amounts $\geq 0.5 \%$ (82 samples $\times 32$ variables $=2624$ data) revealed the existence of a high chemical variability within

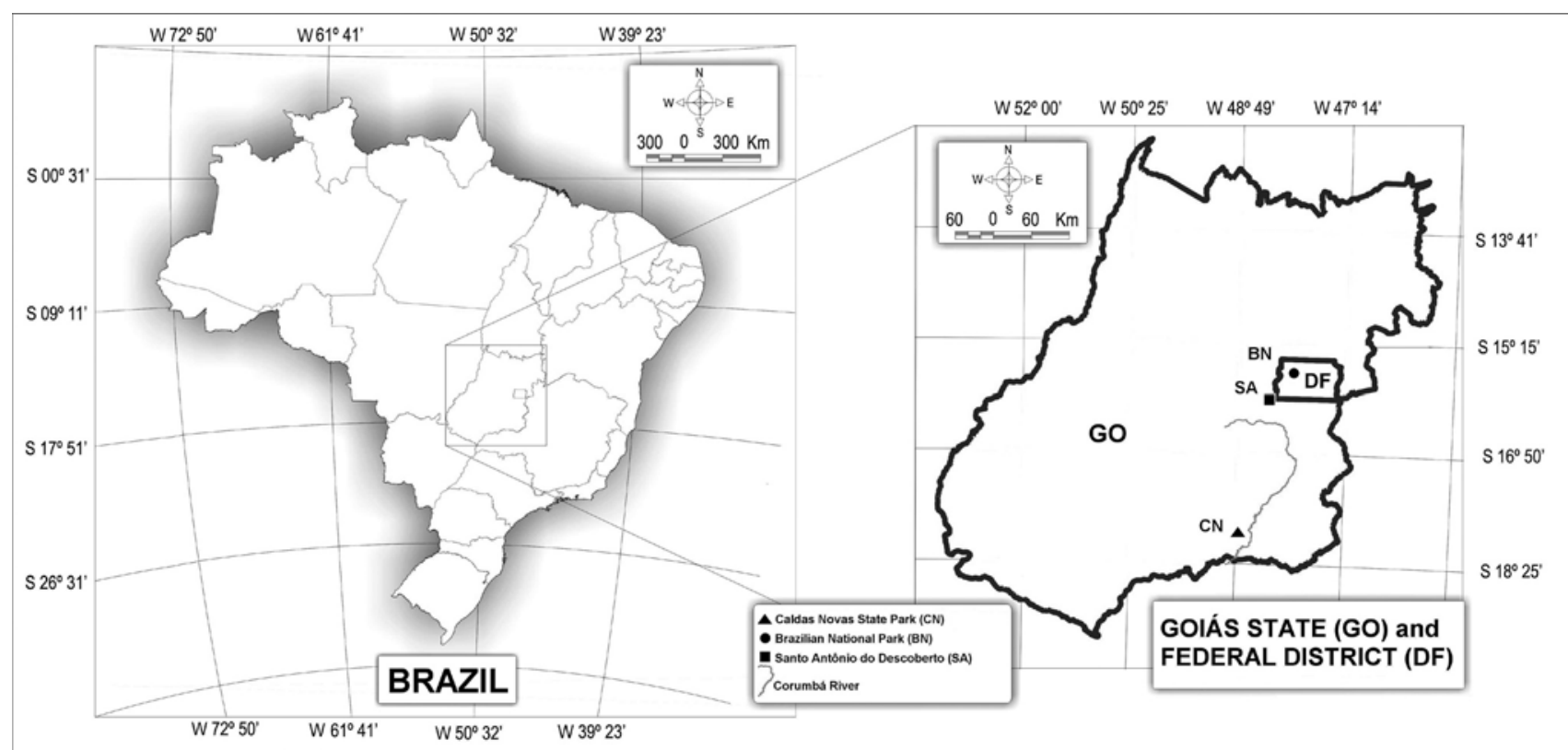

Figure 1. Map of the Brazilian Cerrado region showing the locations of L. ericoides sampling sites: Brasília's National Park (BN), Santo Antônio do Descoberto city (SA), and Caldas Novas' State Park (CN), as well as the Corumbá River basin which geographically separates the CN populations from the BN and SA sites. 
Table 1. Percentages ${ }^{\mathrm{a}}$ of main essential oil constituents from L. ericoides samples with and without scent collected from three sampling sites in the Brazilian Cerrado

\begin{tabular}{|c|c|c|c|c|c|c|}
\hline \multirow{2}{*}{ Constituent } & \multirow{2}{*}{$R_{l}$} & \multirow{2}{*}{ Samples } & \multicolumn{3}{|c|}{ Sampling sites } & \multirow{2}{*}{ Average } \\
\hline & & & $\mathrm{CN}$ & $\mathrm{BN}$ & SA & \\
\hline \multirow{2}{*}{$\alpha$-Thujene } & \multirow{2}{*}{931} & Scent & $13 \mathrm{a}$ & $3.5 \mathrm{~b}$ & $2.9 \mathrm{~b}$ & \\
\hline & & Without scent & - & - & - & \\
\hline \multirow{2}{*}{ Sabinene } & \multirow{2}{*}{973} & Scent & $4.1 \mathrm{a}$ & $2.4 \mathrm{~b}$ & $2.7 \mathrm{ab}$ & \\
\hline & & Without scent & - & - & - & \\
\hline \multirow{2}{*}{$o$-Cymene } & \multirow{2}{*}{1021} & Scent & $17 \mathrm{a}$ & $4.4 \mathrm{~b}$ & $4.6 \mathrm{~b}$ & \\
\hline & & Without scent & - & - & - & \\
\hline \multirow{2}{*}{ Limonene } & \multirow{2}{*}{1025} & Scent & $5.5 \mathrm{a}$ & $2.0 \mathrm{~b}$ & $2.2 \mathrm{~b}$ & \\
\hline & & Without scent & - & - & - & \\
\hline \multirow{2}{*}{$\gamma$-Terpinene } & \multirow{2}{*}{1055} & Scent & $3.7 \mathrm{a}$ & $2.6 \mathrm{a}$ & $3.8 \mathrm{a}$ & \\
\hline & & Without scent & - & - & - & \\
\hline \multirow{2}{*}{ trans-Sabinene hydrate } & \multirow{2}{*}{1098} & Scent & $0.86 \mathrm{a}$ & $5.9 \mathrm{a}$ & $3.6 \mathrm{a}$ & \\
\hline & & Without scent & - & - & - & \\
\hline \multirow{3}{*}{ n-Nonanal } & \multirow{3}{*}{1105} & Scent & 0.44 & 0.32 & 0.10 & $0.29 \mathrm{~A}$ \\
\hline & & Without scent & 9.6 & 1.2 & 0.15 & $3.3 \mathrm{~B}$ \\
\hline & & Average & $4.3 \mathrm{a}$ & $0.67 \mathrm{~b}$ & $0.12 b$ & \\
\hline & & Scent & $6.1 \mathrm{a}$ & $5.5 \mathrm{a}$ & $1.5 \mathrm{~b}$ & \\
\hline Terpin-4-ol & 1176 & Without scent & 0.06 & 0.05 & - & \\
\hline$\alpha$-Ternineol & 1188 & Scent & $1.3 \mathrm{a}$ & $6.5 \mathrm{~b}$ & $2.4 \mathrm{a}$ & \\
\hline$\alpha$-1erpineol & 1188 & Without scent & - & - & - & \\
\hline & & Scent & 0.05 & 1.6 & 0.28 & \\
\hline o-Elemene & 1339 & Without scent & $1.3 \mathrm{a}$ & $8.2 \mathrm{~b}$ & $0.28 \mathrm{~b}$ & \\
\hline & & Scent & - & 0.90 & 0.05 & \\
\hline$\beta$-Maaliene & 1376 & Without scent & $1.2 \mathrm{a}$ & $8.5 \mathrm{~b}$ & $4.9 \mathrm{ab}$ & \\
\hline & & Scent & - & 0.55 & 0.05 & \\
\hline Isocomene & 1384 & Without scent & $0.59 \mathrm{a}$ & $5.4 \mathrm{~b}$ & $3.2 \mathrm{~b}$ & \\
\hline$\gamma$-Curcumene & & Scent & $8.9 \mathrm{a}$ & $3.0 \mathrm{~b}$ & $6.3 \mathrm{a}$ & \\
\hline$\gamma$-curcumene & $14 / 7$ & Without scent & - & - & - & \\
\hline & & Scent & 7.3 & 1.5 & 3.0 & $3.9 \mathrm{~A}$ \\
\hline ar-Curcumene & 1482 & Without scent & 2.8 & 1.5 & 2.0 & $2.1 \mathrm{~B}$ \\
\hline & & Average & $5.4 \mathrm{a}$ & $1.5 \mathrm{~b}$ & $2.5 \mathrm{~b}$ & \\
\hline & & Scent & - & - & - & \\
\hline (E)-Dihydroapofarnesal & 1514 & Without scent & $2.9 \mathrm{ab}$ & $0.49 \mathrm{a}$ & $7.0 \mathrm{~b}$ & \\
\hline$(E)$-Nerolidol & 1561 & Scent & $3.9 \mathrm{a}$ & $1.8 \mathrm{a}$ & - & \\
\hline (L) -1veronduor & 1501 & Without scent & - & - & - & \\
\hline & & Scent & - & - & - & \\
\hline Caryophyllene oxide & 1582 & Without scent & $14 \mathrm{a}$ & $5.5 \mathrm{~b}$ & $13 \mathrm{a}$ & \\
\hline & & Scent & $8.5 \mathrm{Aa}$ & $47 \mathrm{Ab}$ & $45 \mathrm{Ab}$ & \\
\hline$\alpha$-Bisabolol & 1682 & Without scent & $26 \mathrm{Ba}$ & $17 \mathrm{Ba}$ & $25 \mathrm{Ba}$ & \\
\hline Hexadecanoic acid & 1984 & Scent & - & - & - & \\
\hline Hexadecanoic acid & 1984 & Without scent & $3.6 \mathrm{a}$ & $4.2 \mathrm{a}$ & $1.8 \mathrm{a}$ & \\
\hline Monoternene bydrocarhons & & Scent & $43 \mathrm{a}$ & $15 \mathrm{~b}$ & $16 \mathrm{~b}$ & \\
\hline Monoterpene hydrocarbons & & Without scent & - & - & - & \\
\hline & & Scent & $8.3 \mathrm{a}$ & $18 \mathrm{~b}$ & $7.5 \mathrm{a}$ & \\
\hline Oxygenated monoterpenes & & Without scent & 0.06 & 0.05 & - & \\
\hline & & Scent & $16 \mathrm{Aa}$ & $7.5 \mathrm{Ab}$ & $9.6 \mathrm{Aab}$ & \\
\hline Sesquiterpene hydrocarbons & & Without scent & $5.9 \mathrm{Ba}$ & $24 \mathrm{Bb}$ & $18 \mathrm{Bb}$ & \\
\hline Oxyorented sesquiternenes & & Scent & $12.4 \mathrm{Aa}$ & $48 \mathrm{Ab}$ & $45 \mathrm{Ab}$ & \\
\hline Uxygenated sesquiterpenes & & Without scent & $43 \mathrm{Ba}$ & $23 \mathrm{Bb}$ & $45 \mathrm{Aa}$ & \\
\hline & & Scent & 0.44 & 0.32 & 0.10 & $0.29 \mathrm{~A}$ \\
\hline Others & & Without scent & 13 & 5.5 & 2.0 & $6.4 \mathrm{~A}$ \\
\hline & & Average & $5.8 \mathrm{a}$ & $2.3 \mathrm{ab}$ & $1.1 \mathrm{~b}$ & \\
\hline
\end{tabular}

${ }^{a}$ Based on original data. Means followed by the same capital letter in the columns and small letter in the rows did not share significant differences at $5 \%$ probability by Tukey's test. 
the essential oils of L. ericoides. Figure 2 shows the relative position of the individuals in the discriminat space in relation to an axial system originated in the PCA. The First PC accounts for ca. 30\% of total variance and separates monoterpenes of scent sampling (mean content, $36 \pm 17 \%$ ), with minimal differences among most individuals, from mainly sesquiterpenes of samples without scent $(54 \pm 20 \%)$ $(p<0.038)$, while the Second PC distinguishes scent samples from the $\mathrm{CN}$ site according to the content of monoterpene hydrocarbons $(43 \pm 14 \%)(p<0.05)$.

Therefore, two types of essential oils were found, as shown in Figure 2: cluster I with specimens exhibiting an aromatic scent and showing geographical subcluster IA (BN and SA sites), characterised $(p<0.0001)$ by a high percentage of $\alpha$-bisabolol ( $45 \pm 16 \%$ ), and subcluster IB (mainly $\mathrm{CN}$ site) with high levels of $o$-cymene (16 $\pm 6 \%$ ) and $\alpha$-thujene (14 $\pm 6 \%)$; cluster II with specimens devoid of any scent, regardless of the sampling sites, and characterised $(p<0.0001)$ by the highest percentages of caryophyllene oxide $(11 \pm 9 \%)$, $\delta$-elemene $(5.7 \pm 6.9 \%)$, and $\beta$-maaliene $(4.8 \pm 6.5 \%)$. The same hierarchical structure emerges when we consider only terpenes having a maximum contribution to the chemical profile arbitrarily defined at $1 \%(82 \times 111=9102$ data $)$ or when the original data matrix was considered $(82 \times 143=11726$ data $)$. This implies that minor constituents do not substantially interfere with the results of the analyses.

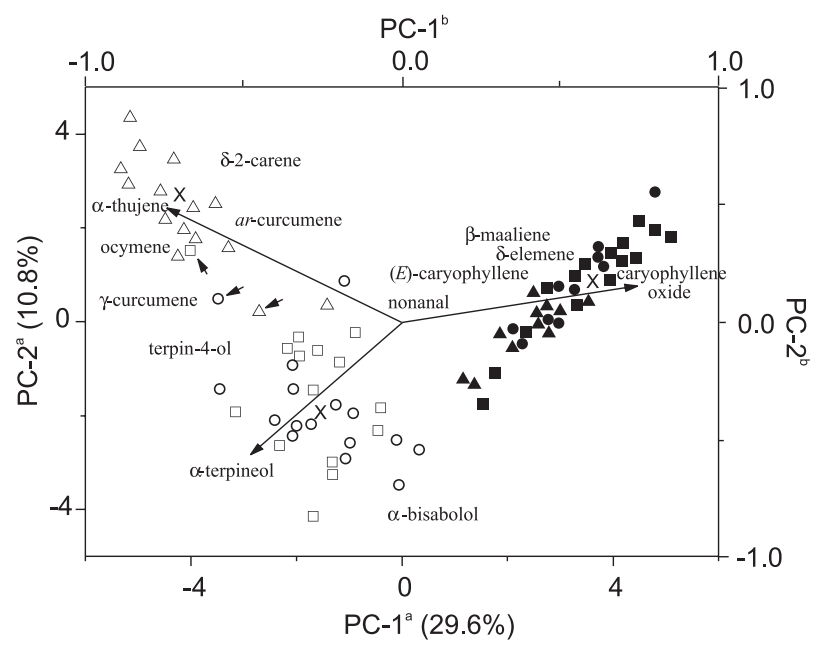

Figure 2. Scatterplot from PCA of L. ericoides samples collected from $\mathrm{BN}$ (circle symbols), SA (square symbols), and CN (triangle symbols) to whose cluster it belongs: I (unshaded symbols) with scent samples showing geographically different subclusters IA (BN/SA) and IB (CN); II (shaded symbols) with scentless samples, regardless of sampling origin. ${ }^{a}$ Axes refer to scores from the samples. ${ }^{\mathrm{b}}$ Axes refer to scores from oil components (Table 1), with predictor variables represented as vectors from the origin. Arrows show misclassification individuals from CDA. Crosses represent cluster centroids and values between parentheses refer to the explained variance on each Principal Component.
In order to assimilate the overall trend in volatile leaf oils and to decrease the uncontrolled factors affecting quantitative variations, the constituent data were also coded as independent single characters (either present or absent) as recommended by Sneath and Sokal. ${ }^{14}$ The multiple correspondence analyses (data not shown) revealed the same consistent chemical distinction between scented and scentless populations sampled.

The canonical discriminant analysis (CDA) confirmed this clustering as a priori groupings and distinguished the different types of essential oils based on the contents of $o$-cymene, $\alpha$-terpineol, and caryophyllene oxide as predictor variables (Table 2). The first discriminant function accounts for $c a$. $85 \%$ of total variability and separated $(p<0.00001)$ scentless samples regardless of the site, according to caryophyllene oxide content, while the second discriminant function distinguished $(p<0.00001)$ scent samples harvested from $\mathrm{BN}$ and $\mathrm{SA}$ sites according to $\alpha$-terpineol. In addition, by using the two discriminant functions, it is possible to accurately predict $96 \%$ well classification in the original clusters by a cross-validation approach. ${ }^{15}$ The only three misclassifications observed were in scent sampling: two of them belong to the BN/SA site (subcluster IA), which were classified as belonging to $\mathrm{CN}$ (subcluster IB), resulting from high amounts of $o$-cymene; while one sample was extracted from the last site, which was classified as belonging to the BN/SA site (subcluster IA) due to a low content of $o$-cymene (see Figure 2).

All these findings may be correlated with factors other than genetic determination, such as biotic pressures which could modulate the volatiles of cluster I (scented samples) from cluster II (scentless samples) or the geographical variations observed in subclusters IA/IB. Leaf volatiles may provide a constitutive defence by deterring potential herbivores. ${ }^{16}$ Monoterpenes, rich in subcluster IB, have been demonstrated to act as toxins by feeding deterrents or oviposition deterrents to a large variety of insects. ${ }^{17}$ It has been shown in other plant species that leaf monoterpenes also attract predators of herbivores. ${ }^{18}$ On the other hand, $\alpha$-bisabolol that has been found in high amounts in subcluster IA has been a specifically-located toxin in trees grazed by snowshoe hare, ${ }^{19}$ although some of the sesquiterpenes found in scentless samples, such as caryophyllene oxide, have also been shown to inhibit pathogens and herbivore attack. ${ }^{20}$

As stated by Levin et al., ${ }^{21}$ variation in volatiles may also reflect factors other than plant defence, including current environmental conditions and evolutionary history, and furthermore, samples with more volatile constituents could be favoured by pollinators. In this study, the Corumbá 
Table 2. Canonical discriminant analysis summary of L. ericoides

\begin{tabular}{|c|c|c|c|c|c|c|c|}
\hline A. Canonical discriminant functions & Eigenvalue & $\begin{array}{l}\text { Relative } \\
\text { percentage }\end{array}$ & $\begin{array}{l}\text { Canonical } \\
\text { correlation }\end{array}$ & $\begin{array}{l}\text { Wilks' } \\
\text { lambda }\end{array}$ & $F$ & $D F$ & $P$-value \\
\hline$\overline{F 1}$ & 4.020 & 84.1 & 0.985 & 0.113 & 50.679 & $6 ; 154$ & 0.00001 \\
\hline $\mathrm{F} 2$ & 0.762 & 15.9 & 0.657 & 0.567 & 29.735 & $2 ; 78$ & 0.00001 \\
\hline B. Standardized coefficients & $o$-Cymene & $\alpha$-Terpineol & \multicolumn{5}{|c|}{ Caryophyllene oxide } \\
\hline $\mathrm{F} 1$ & 0.898 & 0.326 & \multicolumn{5}{|l|}{-0.413} \\
\hline $\mathrm{F} 2$ & 0.414 & -0.685 & \multicolumn{5}{|l|}{0.527} \\
\hline \multirow[t]{3}{*}{ C. Cross-validation } & \multicolumn{7}{|c|}{ Percentage of total well-classification } \\
\hline & $o$-Cymene & $\alpha$-Terpineol & \multirow{2}{*}{\multicolumn{2}{|c|}{ Caryophyllene oxide }} & Total & & \\
\hline & 94 & 93 & & & 96 & & \\
\hline
\end{tabular}

Number of samples $=82$; discriminant variables: $o$-cymene, $\alpha$-terpineol, caryophyllene oxide.

River Basin geographically separates the CN populations from the $\mathrm{BN}$ and $\mathrm{SA}$ sites (Figure 1), and L. ericoides does not occur in lower altitude areas corresponding to the depression formed by the river and its tributaries. ${ }^{12}$ At least partially, this spatial barrier could contribute to an ecological isolation, a pre-requisite for speciation and chemovariation between the scented samples (subclusters IA from IB).

A related variation in the eremantholide-type sesquiterpene lactones isolated from $L$. ericoides leaves seems to accompany this same phytogeographical distribution. ${ }^{7}$ Although these authors have not commented on scent characteristics in the specimens sampled from different locations $\left(16^{\circ} \mathrm{S}\right.$ to $\left.21^{\circ} \mathrm{S}\right)$, including the neighbourhood of SA and $\mathrm{CN}$ sites, the results revealed the absence of oxidised sesquiterpene lactones with an increase in latitude. A similar oxidative gradient was described for monoterpenes and sesquiterpenes from Hyptis suaveolens (L.) Poit. (Lamiaceae) leaves and for aerial parts of Baccharis trimera (Less.) DC. (Asteraceae) harvested along the same latitudes. ${ }^{22}$

Another implication extracted from the present data is that the influence of edapho-climactic factors in each sampling site, an opposing view to that of Curado et al., ${ }^{12}$ is not strong enough to induce the high chemical variability recorded in the leaf oil. Here it might be speculated that the phenotypic plasticity of L. ericoides, which ultimately results in a qualitative difference of scent, could be the main factor contributing to differences in the essential oil profiles of all natural populations growing in the same sampling sites.

Unlike the previous ecotypic study of this species the existence of chemotypic differentiation could be concluded, because of plants grown in the same environments at each sampling site. ${ }^{12}$ However, we cannot exclude the presence of two subspecies growing in the same habitat, according to considerations by Coile and Jones, ${ }^{1}$ into which L. ericoides might possibly be subdivided.

\section{Conclusions}

Essential oil from L. ericoides grown on the Brazilian Cerrado revealed a high polymorphism, with two types of oil coexisting in all the populations under study. The variability observed between clusters I and II seems to be genetically determined, whereas between subclusters IA/IB it clearly seems to be the result of different evolutive pressures acting as a force for selection of specialised phenotype which is better adapted to local environments. In addition, results indicated that a proper exploitation of the medicinal properties of this species during selection, germplasm conservation, breeding, and domestication, demands consideration not only of morphological aspects and scent occurrences, but also of location of the sampling site that contributes positively to the herb's medicinal value.

\section{Experimental}

\section{Plant material}

Leaves of L. ericoides were collected at the mature vegetative stage in January-March 2001 from their natural habitats and were identified by one of the authors (R.F.V.). 10-16 randomised individual plants representing the local population with or without scent, in a total of 82 individuals, were collected from each of three localities: Brasília's National Park (BN), S 15³9' 39', W 47 56' 28', 1111 m; Santo Antônio do Descoberto city (SA), S $15^{\circ} 57^{\prime}$ 11", W 48 14' 36", 912 m, and Caldas Novas' State Park (CN), S $17^{\circ} 50$ ' 55', W 48 41' 7', 1023 m (Figure 1). Voucher specimens of each accession have been deposited in the Herbarium of Embrapa Recursos Genéticos e Biotecnologia (CEN), DF, Brazil.

The leaf samples were dried in an oven with circulating air, at temperature of $30^{\circ} \mathrm{C}$ for 2 days until constant weight. Then, the total plant material from each population was 
chopped and submitted to hydrodistillation ( $2 \mathrm{~h}$ ) by using a modified Clevenger apparatus. Oil yields $(\%)$ were based on the dry weight of plant samples.

\section{Essential oil analyses}

Oil sample analyses were performed on a GC-MS Shimadzu QP5050A employing the following conditions: a column CBP-5 (Shimadzu) fused silica capillary column $(30 \mathrm{~m} \times 0.25 \mathrm{~mm}$ i.d. $\times 0.25 \mu \mathrm{m}$ film thickness composed of $5 \%$ phenylmethylpolysiloxane) connected to a quadrupole detector operating in the EI mode at $70 \mathrm{eV}$ with a scan mass range of $40-440 \mathrm{~m} / \mathrm{z}$ at a sampling rate of $1.0 \mathrm{scan} \mathrm{s}^{-1}$; carrier gas: $\mathrm{He}\left(1 \mathrm{~mL} \mathrm{~min}^{-1}, 56.7 \mathrm{kPa}\right)$; injector and interface temperatures were $220{ }^{\circ} \mathrm{C}$ and $240{ }^{\circ} \mathrm{C}$, respectively. Injection volume was $0.4 \mu \mathrm{L}(20 \%$ in $\mathrm{CH}_{2} \mathrm{Cl}_{2}$ ) in the split mode with a split ratio of 1:20 and the oven temperature was raised from $60{ }^{\circ} \mathrm{C}$ to $240{ }^{\circ} \mathrm{C}$ at $3{ }^{\circ} \mathrm{C} \mathrm{min}{ }^{-1}$, then to $270{ }^{\circ} \mathrm{C}$ at $10^{\circ} \mathrm{C} \mathrm{min}^{-1}$, holding the final temperature for $5 \mathrm{~min}$.

Individual components were identified by comparing their retention indexes made through co-injection with a $\mathrm{C}_{8}-\mathrm{C}_{32}$ n-alkanes series, ${ }^{23}$ mass spectra with those of the literature, and a computerised MS-data base using NIST libraries. ${ }^{24,25}$ Major compounds were also identified by ${ }^{13} \mathrm{C}$ NMR spectroscopic analysis using a Varian Gemini spectrometer operating at $75 \mathrm{MHz}$ with $\mathrm{C}_{6} \mathrm{D}_{6}$ as internal reference. The identification was performed by an analysis of the ${ }^{13} \mathrm{C}$ NMR spectrum of the total oil, by comparing the signals obtained with those in the literature. ${ }^{26}$

\section{Statistical analysis}

Principal component (PCA) and multiple correspondence analysis were applied in order to examine the interrelationships between populations and their chemical constituents such as amount or presence/absence code using Système Portable d'Analyse des Données Numériques-SPAD.N software package, version 2.5 (Centre International de Statistique et d'Informatique Appliquées, France, 1994). Cluster analysis was also applied to the study of similarity of samples on the basis of constituent distribution. Nearest neighbour complete linkage technique by Benzécri algorithm was used as an index of similarity and hierarchical clustering was performed according to Ward's variance minimising method. ${ }^{27,28}$

Canonical discriminant analysis using SAS CANDISC procedure (Statistical Analysis System, SAS Institute Inc., Cary, NC, 1996) was used to differentiate the harvested sampling according to sampling sites and scent. The predictive ability of canonical discriminant functions was evaluated by cross-validation, leaving one group approach as implemented in SAS statistical package.

Two-way ANOVA (scent and sites as factors) was used to compare total constituent abundances using SAS GLM analyses. All data were checked for homoscedasticity with Hartley's test. This test revealed significant departures from the basic assumption for the oil components $\alpha$-thujene, $o$-cymene, terpin-4-ol to $\delta$-elemene, hexadecanoic acid, oxygenated monoterpenes (Table 1) and for trans-sabinene hydrate, n-nonanal, $\beta$-maaliene to caryophyllene oxide, total sesquiterpene hydrocarbons and other constituents, which were arcsine and rank-transformed, respectively. ${ }^{29}$ Whenever a difference was established, a post-hoc Tukey test was performed. $P$-values less than 0.05 were considered to be significant.

\section{Acknowledgments}

The authors are indebted to PADCT III, FUNAPE/UFG, and FNMA for financial support. Thanks are also due to Nilton C. Soares and Prof. Dr Ronaldo A. Pilli of Instituto de Química-UNICAMP for ${ }^{13} \mathrm{C}$ NMR data.

\section{Supplementary Information}

Supplementary data are available free of charge at http://jbcs.sbq.org.br, as a PDF file.

\section{References}

1. Coile, N. C.; Jones, S. B.; Brittonia 1981, 33, 528.

2. Semir, J.; PhD Thesis, Universidade Estadual de Campinas, Brazil, 1993.

3. Robinson, H.; Proc. Biol. Soc. Wash. 1992, 105, 640; Mansanares, M. E.; Formi-Martins, E. R. F.; Semir, J.; Caryologia 2002, 55, 367.

4. Borsato, M. L. C.; Grael, C. F. F.; Souza, G. E. P.; Lopes, N. P.; Phytochemistry 2000, 55, 809.

5. Cerqueira, M. B. S.; Souza, J. T.; Júnior, R. A.; Peixoto, A. B. F.; Ciênc. Cult. 1987, 39, 551; Kanashiro, A.; Kabeya, L. M.; Polizello, A. C. M.; Lopes, N. P.; Lopes, J. L. C.; LucisanoValim, Y. M.; Phytother. Res. 2004, 18, 61; Ferraz Filha, Z. S.; Vitolo, I. F.; Fietto, L. G.; Lombardi, J. A.; Saúde-Guimarães, D. A.; J. Ethnopharmacol. 2006, 107, 79.

6. Santos, P. A.; Amarante, M. F. C.; Pereira, M. A. S.; Bertoni, B.; Franca, S. C.; Pessoa, C.; De Moraes, M. O.; Costa-Lotufo, L. V.; Pereira, M. R. P.; Lopes, N. P.; Chem. Pharm. Bull. 2005, 52, 1433.

7. Borella, J. C.; Lopes, J. L. C.; Vichnewski, W.; Cunha, W. R.; Herz, W.; Biochem. Syst. Ecol. 1998, 26, 671. 
8. Sakamoto, H. T.; Flausino, D.; Castellano, E. E.; Stark, C. B. W.; Gates, P. J.; Lopes, N. P.; J. Nat. Prod. 2003, 66, 693.

9. Gobbo-Neto, L.; Santos, M. D.; Kanashiro, A.; Almeida, M. C.; Lucisano-Valim, Y. M.; Lopes, J. L. C.; Souza, G. E. P.; Lopes, N. P.; Planta Med. 2005, 71, 3.

10. Sargenti, S. R.; Vichnewski, W.; Phytochem. Anal. 2000, 11, 69.

11. Santos, M. D.; Gobbo-Neto, L.; Albarella, L.; Souza, G. E. P.; Lopes, N. P.; J. Ethnopharmacol. 2005, 96, 545.

12. Curado, M. A.; Oliveira, C. B. A.; Jesus, J. G.; Santos, S. C.; Seraphin, J. C.; Ferri, P. H.; Phytochemistry 2006, 67, 2363.

13. Szoke, E.; Maday, E.; Tyihak, E.; Kuzovkina, I. N.; Lemberkovics, E.; J. Chromatogr. B 2004, 800, 231.

14. Sneath, P. H.; Sokal, R. R.; Principles of Numerical Taxonomy, W.H. Freeman: San Francisco, 1963.

15. Wold, A.; Eriksson, L. In Chemometric Methods in Molecular Design, vol. 2; Waterbeemd, H., ed.; VCH: Weinheim, 1995, ch. 5 .

16. Städler, E. In Herbivores, their Interactions with Secondary Plant Metabolites, vol. 2; Rosenthal, G. A., Berenbaum, M. R., eds.; Academic Press: San Diego, 1992, p. 45.

17. Gershenzon, J.; Croteau, R. In Herbivores, their Interactions with Secondary Plant Metabolites, vol. 1; Rosenthal, G. A., Berenbaum, M. R., eds.; Academic Press: New York, 1991, p. 165; Theis, N.; Lerdau, M.; Int. J. Plant Sci. 2003, 164, 93.

18. Dicke, M.; Biochem. Syst. Ecol. 2000, 28, 601; Dicke, M.; Hilker, M.; Basic Appl. Ecol. 2003, 4, 3.

19. Harborne, J. B. In Plant Biochemistry. Dey, P. M., Harborne, J. H., eds.; Academic Press: New York, 1997, p. 503.
20. Sturgeon, K. B.; Evolution 1979, 33, 803; Langenheim, J. H.; J. Chem. Ecol. 1994, 20, 1223.

21. Levin, R. A.; McDade, L. A.; Raguso, R. A.; Syst. Biol. 2003, 52,334 .

22. Azevedo, N. R.; Campos, I. F. P.; Ferreira, H. D.; Portes, T. A.; Santos, S. C.; Seraphin, J. C.; Paula, J. R.; Ferri, P. H.; Phytochemistry 2001, 57, 733; Silva, F. G.; Oliveira, C. B. A.; Pinto, J. E. B. P.; Nascimento, V. E.; Santos, S. C.; Seraphin, J. C.; Ferri, P. H.; J. Braz. Chem. Soc. 2007, 18, 990.

23. van Den Dool, H.; Kratz, P. D. J. A.; J. Chromatogr. 1963, 11, 463.

24. Adams, R. P.; Identification of Essential Oil Components by Gas Chromatography/Mass Spectrometry, $4^{\text {th }}$ ed., Allured: Illinois, 2007.

25. National Institute of Standards and Technology; PC version of the NIST/EPA/NIH Mass Spectral Database, U.S. Department of Commerce: Gaithersburg, 1998.

26. Kubeczka, K. -H.; Formácek, V.; Essential Oils Analysis by Capillary Gas Chromatography and Carbon-13 NMR Spectroscopy, $2^{\text {nd }}$ ed., John Wiley \& Sons: New York, 2002.

27. Benzécri, J. -P.; L'Analyse des Données: la Taxinomie, Tome 1, Dunod: Paris, 1980.

28. Ward, J. H.; J. Am. Stat. Assoc. 1963, 58, 238.

29. Conover, W. J.; Practical Nonparametric Statistics, $3^{\text {rd }}$ ed., John Wiley \& Sons: New York, 1999, p. 417.

Received: May 4, 2007

Web Release Date: March 31, 2008 


\section{Infraspecific Variability in the Essential Oil Composition of Lychnophora ericoides}

Cynthia C. G. V. Lyra, ${ }^{a}$ Roberto F. Vieira, ${ }^{b}$ Carolina B. A. de Oliveira, ${ }^{c}$ Suzana C. Santos, ${ }^{c}$ José C. Seraphin ${ }^{d}$ and Pedro H. Ferri ${ }^{c, *}$

${ }^{a}$ Universidade Católica de Brasília, SGAN 916 Módulo B, 70790-160 Brasília-DF, Brazil

${ }^{b}$ Embrapa Recursos Genéticos e Biotecnologia, CP 02372, 70770-900 Brasília-DF, Brazil ${ }^{c}$ Laboratório de Bioatividade Molecular, Instituto de Química, Universidade Federal de Goiás, CP 131, 74001-970 Goiânia-GO, Brazil

${ }^{d}$ Núcleo de Estatística Aplicada, Instituto de Matemática e Estatística, Universidade Federal de Goiás, CP 131, 74001-970 Goiânia-GO, Brazil



Figure S1. ${ }^{13} \mathrm{C}-\mathrm{NMR}\left(75 \mathrm{MHz}, \mathrm{C}_{6} \mathrm{D}_{6}\right)$ of essential oil from leaves of L. ericoides with and without scent, which consist mainly of $\alpha$-bisabolol (marked signals). 


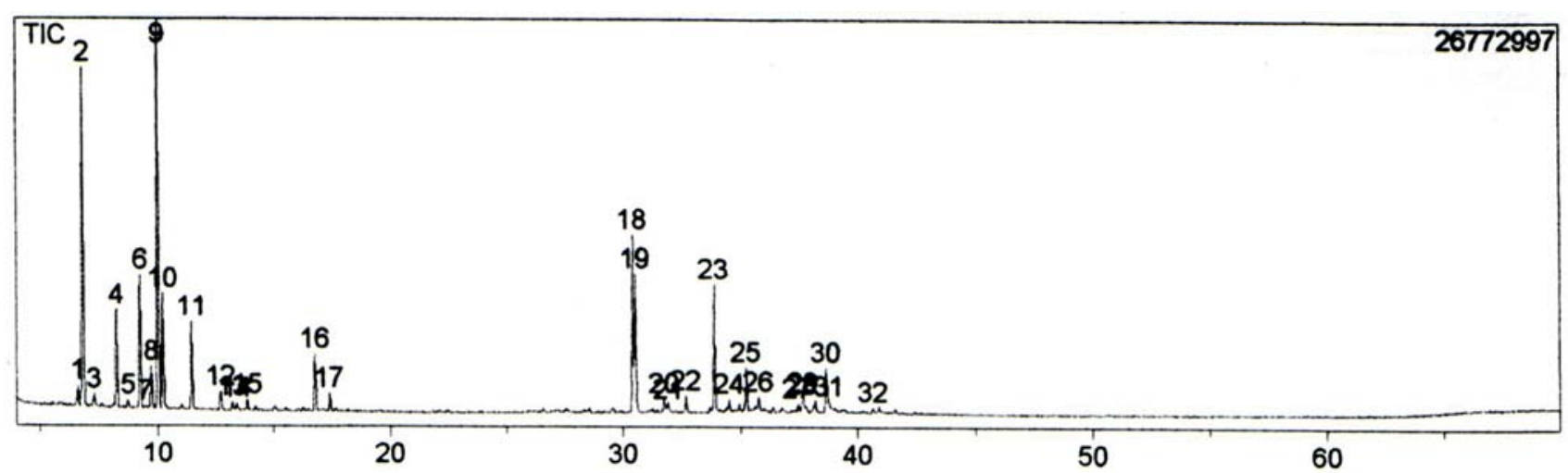

Figure S2. Total Ion Chromatogram (TIC) of essential oil from leaves of L. ericoides with scent collected in Caldas Novas' State Park (CN).

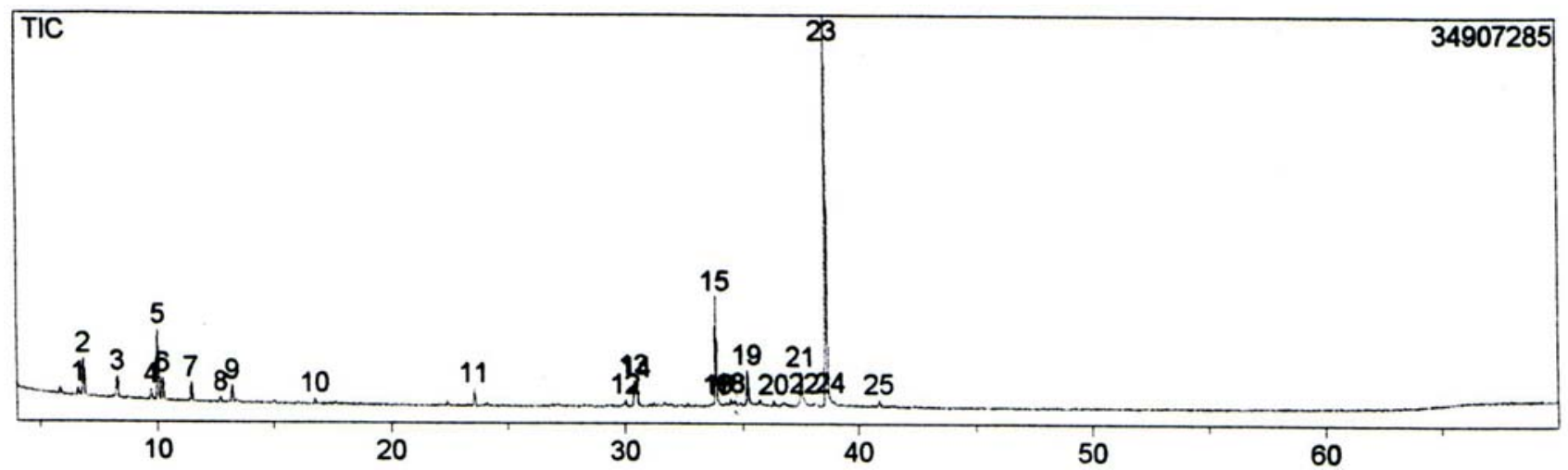

Figure S3. TIC of essential oil from leaves of L. ericoides without any scent collected in Caldas Novas' State Park (CN).

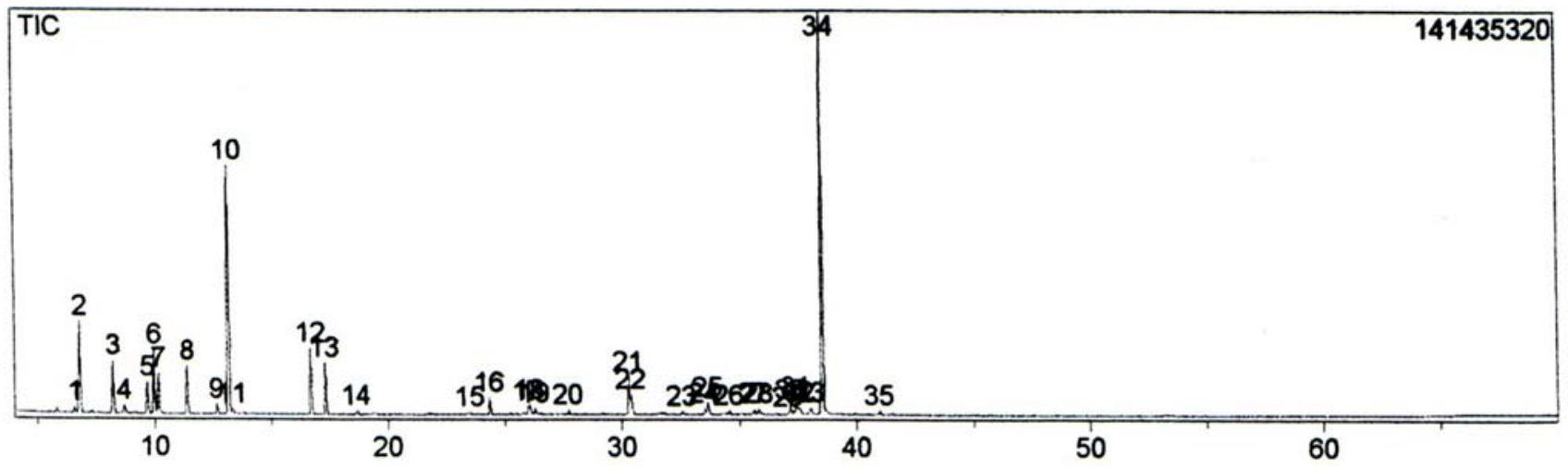

Figure S4. TIC of essential oil from leaves of L. ericoides with scent collected in Brasília's National Park (BN). 


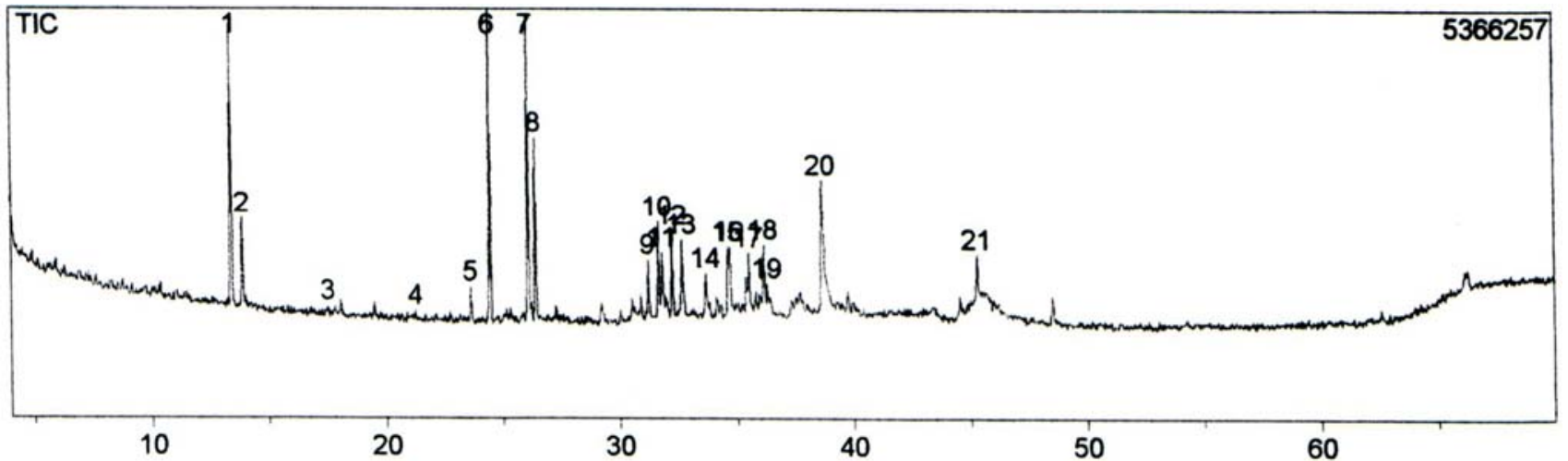

Figure S5. TIC of essential oil from leaves of L. ericoides without any scent collected in Brasília's National Park (BN).



Figure S6. TIC of essential oil from leaves of L. ericoides with scent collected in Santo Antônio do Descoberto site (SA).

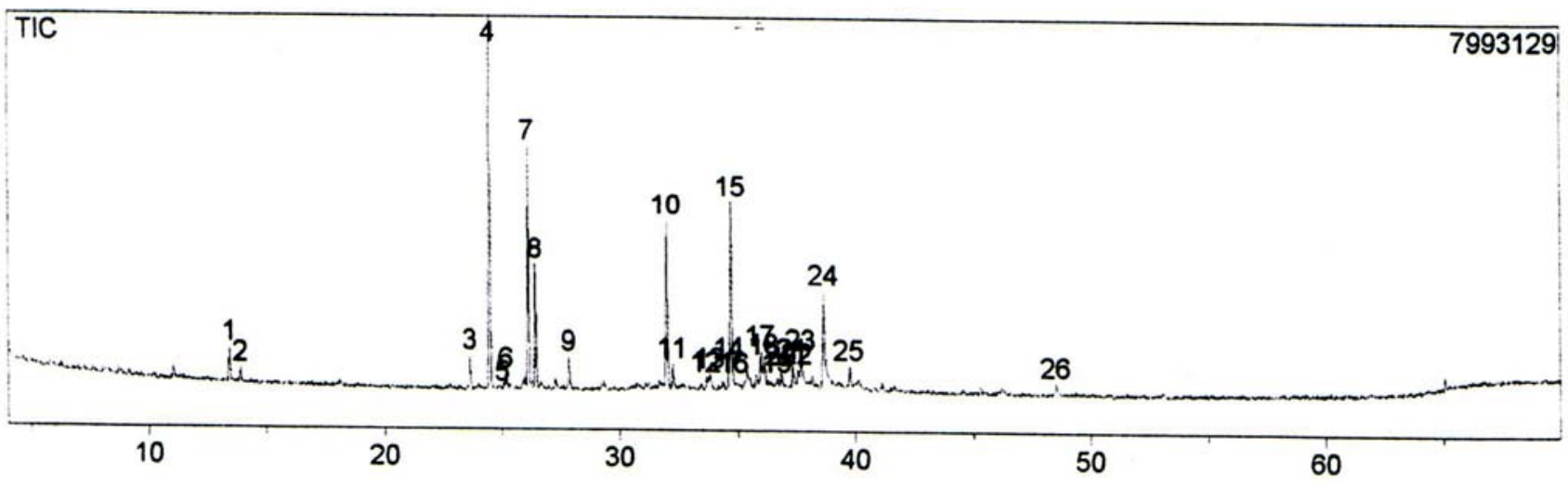

Figure S7. TIC of essential oil from leaves of L. ericoides without any scent collected in Santo Antônio do Descoberto site (SA). 


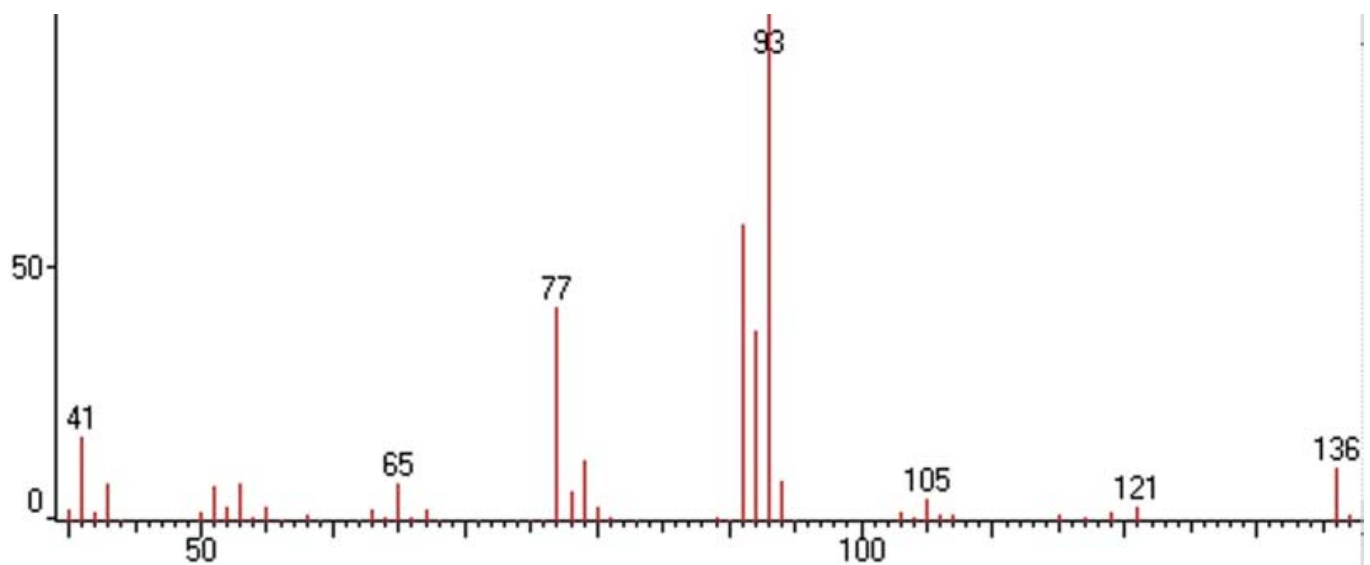

Figure S8. Mass spectrum of $\alpha$-thujene.

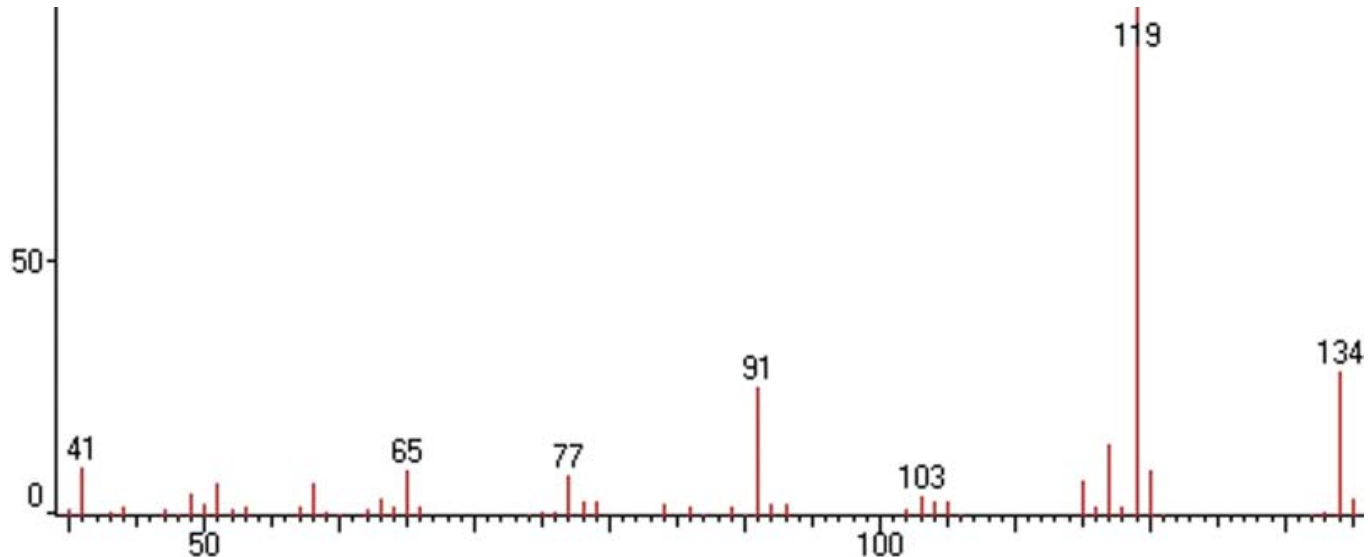

Figure S9. Mass spectrum of $o$-cymene.



Figure S10. Mass spectrum of terpin-4-ol. 




Figure S11. Mass spectrum of $\delta$-elemene.



Figure S12. Mass spectrum of $\beta$-maaliene.

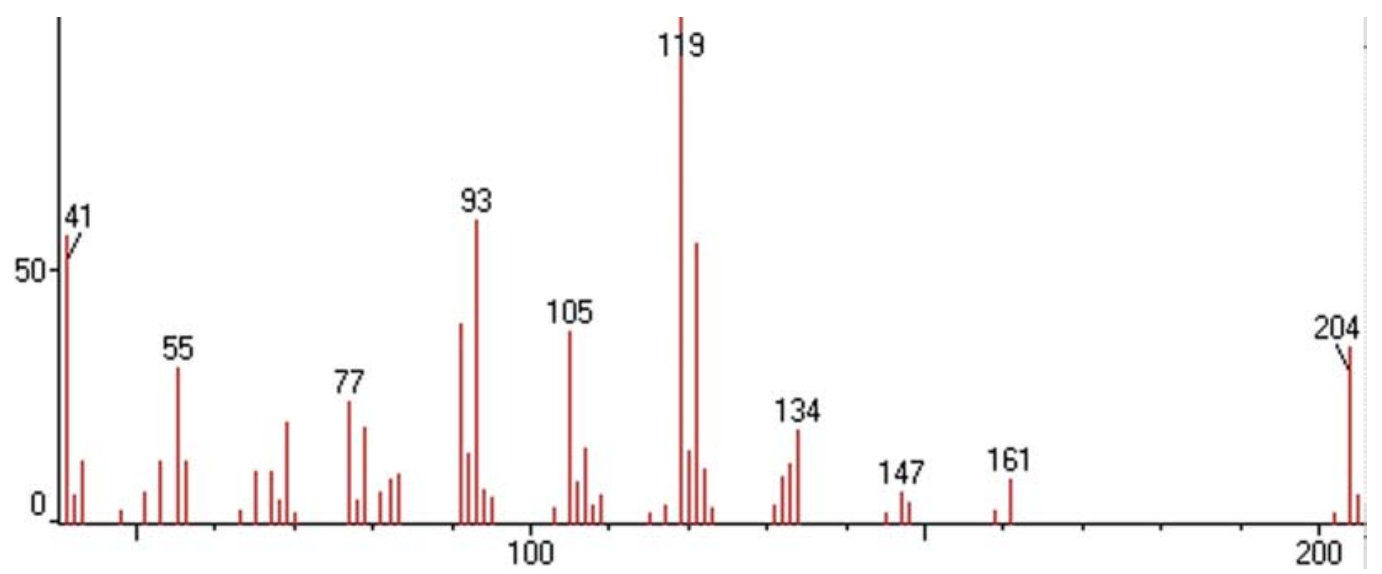

Figure S13. Mass spectrum of $\gamma$-curcumene. 


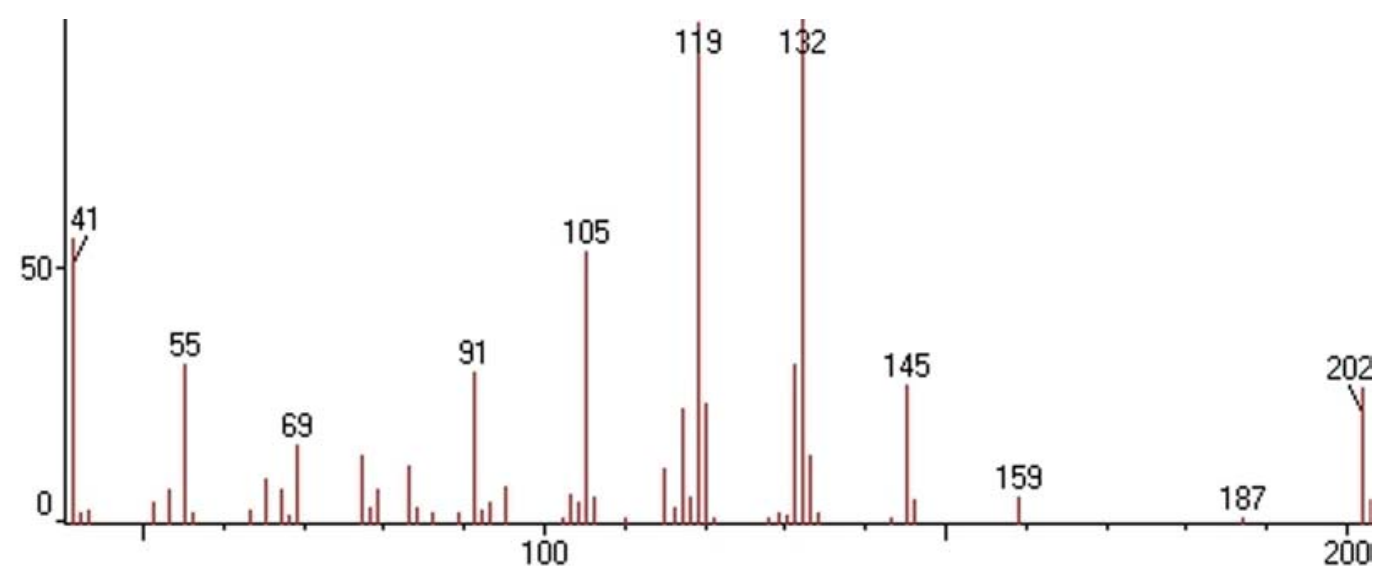

Figure S14. Mass spectrum of ar-curcumene.

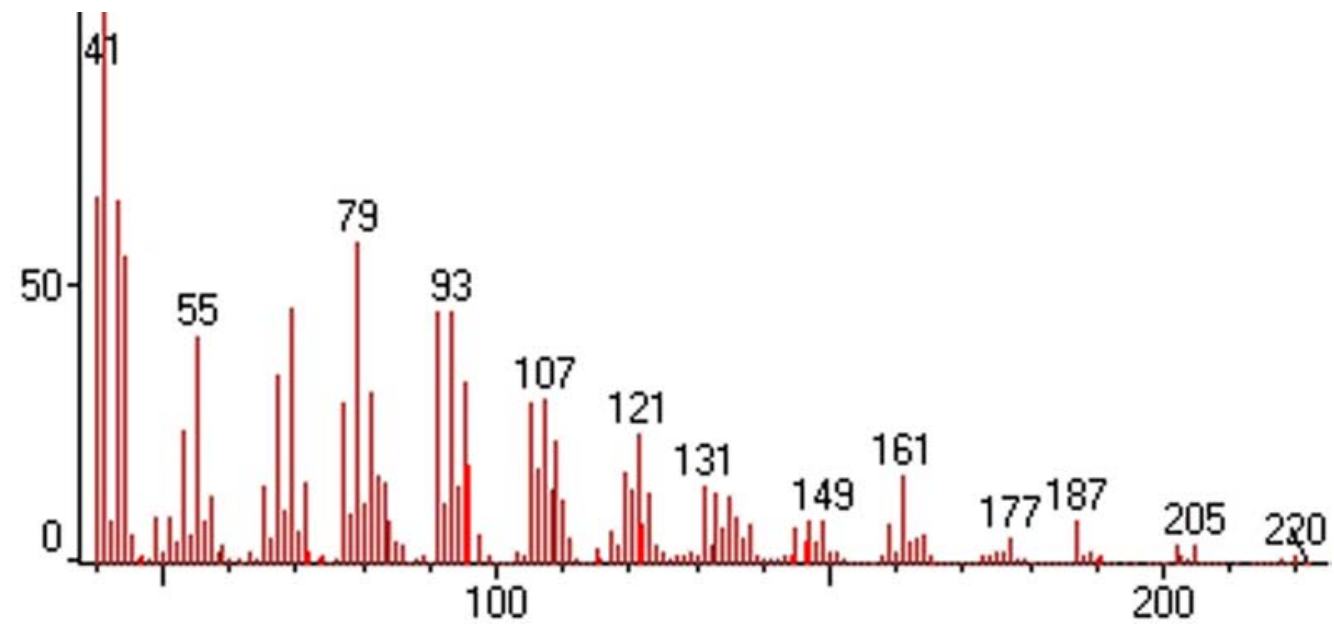

Figure S15. Mass spectrum of caryophyllene oxide.

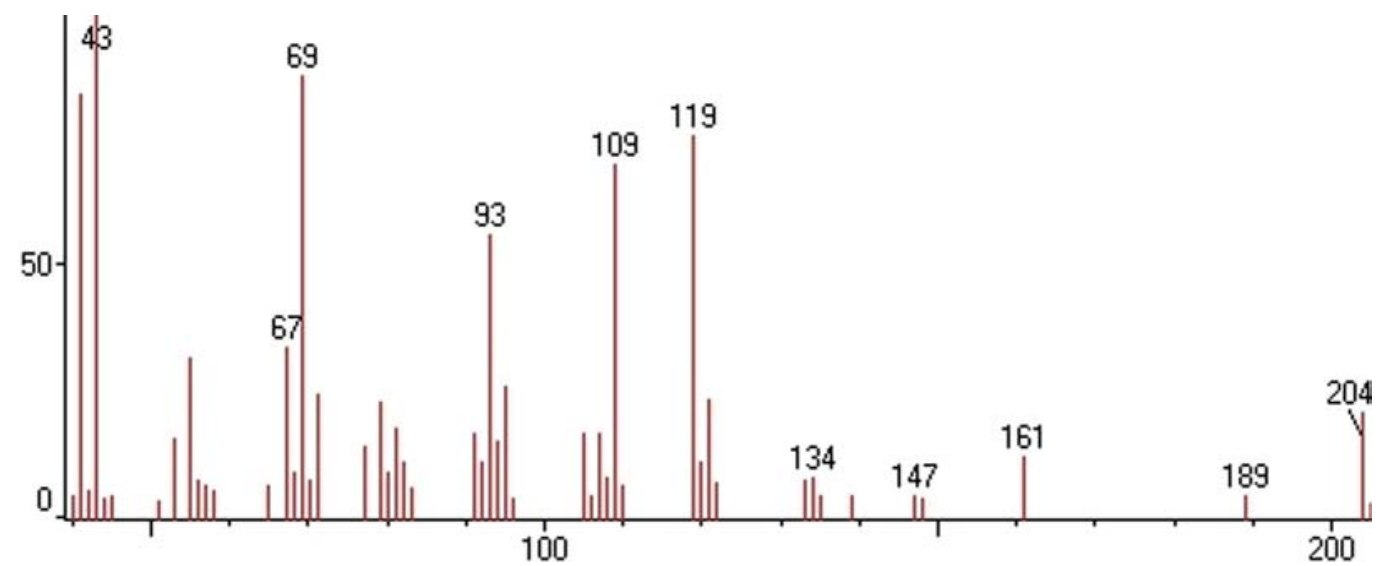

Figure S16. Mass spectrum of $\alpha$-bisabolol. 